\title{
ANALISIS STRATEGI PEMASARAN PRODUK KONVEKSI DAN AKSESORIS PADA TOKO UD. GINA RIA KECAMATAN TERARA LOMBOK TIMUR
}

\author{
Nurul Hidayah ${ }^{1}$ \\ ${ }^{\text {I}}$ Fakultas Ekonomi dan Bisnis Universitas Mataram,_Uyunkhidayah8@gmail.com
}

\begin{abstract}
ABSTRAK
Penelitian ini berjudul Analisis Strategi Pemasaran Produk Konveksi dan Aksesoris Pada Toko UD. Gina Ria. Tujuan dan penelitian ini adalah untuk mengetahui posisi UD.Gina Ria dalam pemasarannya berdasarkan analisis internal dan eksternal, untuk mengetahui strategi apa yang tepat untuk digunakan oleh toko UD. Gina Ria dilihat dan analisis internal dan eksternal.

Jenis metode penelitian yang digunakan adalah deskriptif dengan tujuan untuk memeperoleh gambaran terhadap faktor-faktor lingkungan internal dan ekstennal kemudian menganalisis menggunakan analisisi SWOT. Jumlah responden dalam penelitian ini adalah 21 orang yang dibagi menjadi responden internal perusahaan sebanyak 13 orang dan sisanya adalah eksternal perusahaan yang menjadi tringulasi. Alat pengumpulan data berupa kuesioner dengan angket sebagai teknik pengumpulan data. Skala pengukuran menggunakan skala likert. Analisis data yang digunakan adalah analisis SWOT. Setelab melakukan wawancara dengan pemilik UD. Gina Ria dan hasil analisis SWOT, didapatkan bahwa posisi UD. Gina Ria berada pada kuadran 1 yang berarti UD. Gina Ria berada pada posisi kuat dan berpeluang.
\end{abstract}

Kata Kunci: Analisis SWOT, Lingkungan Internal, Lingkungan Eksternal

\section{ABSTRACT}

This study entitled Analysis of Product Strategy Convection and Accessories At UD Shop. Gina Ria. The purpose of this research is to know the position of UD. Gina Ria in marketing based on internal and external analysis, to know what strategy is appropriate for use by UD shop. Gina Ria is seen from internal and external analysis.

The type of research method used is descriptive with the aim to obtain an overview of internal and external environmental factors then analyze using SWOT analysis. The number of respondents in this study were 21 people divided into internal respondents as many as 13 people and the rest are external companies that become tringulasi. Data collection tool in the form of questionnaire with questionnaire as data collection technique. Measurement scale using Likert scale. Data analysis used is SWOT analysis. After interviewing the owner of UD. Gina Ria and result of SWOT analysis, got that position of UD. Gina Ria is in quadrant 1 which means UD Gina Ria is in a strong position and a chance.

Keywords: SWOT Analysis, Internal Environment, External Environment. 


\section{PENDAHULUAN}

Pertumbuhan ekonomi Indonesia yang semakin membaik mendorong timbulnya laju persaingan di dalam dunia usaha. Hal ini dapat kita lihat dengan semakin banyaknya perusahaan yang menghasilkan barang maupun jasa, yang menyebabkan persaingan dalam dunia usaha semakin ketat. Dalam kondisi semakin meningkatnya persaingan antara produk-produk sejenis, maka perusabaan yang satu dengan yang lain saling bersaing untuk merebut konsumen. Kesuksesan dalam persaingan akan dapat dipenuhi apabila perusahaan bisa menciptakan dan mempertahankan pelanggan (Tjiptono, 2002:19).

Menurut Kotler (1997) Strategi pemasaran adalah cara di mana fungsi pemasaran menyelenggarakan kegiatannya untuk mencapai pertumbuhan yang menguntungkan dalam penjualan path level "marketing mix" Kotler, 1997. Berdasarkan pengertian di atas maka sebuah strategi pemasaran perlu dipertahankan karena akan memberikan kesatuan arah bagi anggota organisasi. Dua hal yang mendasari pilihan strategi bersaing yaitu: penentuan posisi bersaing perusahaan secara relatif berkaitan dengan perbedaan kemampuan masing-masing perusahaan dalam menghasilkan laba dan kedua adalah daya tank industri untuk menghasilkan laba dalam jangka panjang dan faktor-faktor yang menentukan kemampuan tersebut.

Pokok perumusan strategi bersaing adalah menghubungkan perusahaan dalam lingkungannya, walaupun Iingkungan yang relevan sangat luas meliputi:

Kekuatan sosial sebagaimana juga kekuatan ekonomi, aspek utama dan lingkungan perusahaan adalah industri-industri dalam perusahaan bersaing. Struktur industri memiliki pengaruh yang kuat dalam menentukan aturan permainan bersaing selain juga strategi - strategi yang secara potensial tersedia bagi perusahaan. Kekuatankekuatan dan luar indusrti penting terutama dalam artian yang relatif karena kekuatan sangat mempengaruhi semua perusahaan yang ada dalam suatu industri maka kuncinya terletak pada kemampuan yang berlainan di antara perusahaan.

Sebelum perusahaan dapat memulai perumusan strateginya, terlebih dahulu harus mengamati lingkungan eksternal dan internal untuk mengidentifikasi kekuatan dan kelemahan perusahaan juga akan menentukan apakah perusahaan mampu mengambil keuntungan dan peluang yang ada sambil menghindani ancaman. Untuk mencapai tujuannya, perusahaan harus mampu mempertahankan pangsa pasar yang ada dengan membina hubungan baik dengan pelanggan. Tujuan tersebut dapat dicapai melalui upaya untuk dapat mempertahankan dan meningkatkan keuntungan operasional perusahaan. Hal ini dapat dilakukan jika perusahaan dapat mempertahankan dan meningkatkan penjualan produk atau jasa yang mereka produksi. Dengan menerapkan strategi pemasaran yang akurat melalui pemanfaatan peluang dalam meningkatkan penjualan, selanjutnya dengan tujuan dan sasaran yang terlebih dahulu melalui analisis lingkungan internal dan eksternal perusahaan. Dalam rangka mewujudkan tujuan dan sasaran tersebut, maka perlu ditentukan strategi pemasaran yang cocok bagi perusahaan.

Strategi pemasaran pada dasarnya adalah rencana yang menyeluruh, terpadu dan menyatu di bidang pemasaran yang memberikan panduan tentang kegiatan yang akan dijalankan untuk dapat tercapainya tujuan pemasaran suatu perusahaan. Menurut Sastradipoera $(2003,38)$ strategi pemasaran adalah rencana untuk mencapai tujuantujuan organisasi di bidang pemasaran. Dengan kata lain, strategi pemasaran adalah serangkaian tujuan dan sasaran, kebijakan dan aturan yang memberi arah kepada usahausaha pemasaran perusahaan dan waktu ke waktu, pada masing-masing tingkatan dan 
acuan serta alokasi, terutama sebagai tanggapan perusahan dalam menghadapi lingkungan dan keadaan persaingan yang selalu berubah.

Penentuan strategi pemasaran dalam suatu pemasaran merupakan suatu kegiatan yang sangat kompleks dan saling berhubungan, karena merupakan usaha mencapai tujuan dengan memberikan arah dan kebijakan dasar yang berkaitan dengan perusahaan. Dimana rencana untuk mencapai tujuan tersebut dirumuskan sedemikian rupa sehingga jelas usaha yang sedang dan akan dilaksanakan dalam memasarkan suatu produk yang dihasilkan oleh perusahaan tersebut. Menurut Tjiptono (2002) di dalam suatu perusahaan terdapat 3 level strategi, yaitu level korporasi, level unit bisnis atau lini bisnis, dan level fungsional. Dalam proses penyusunan strategi perusahaan kita harus memperhatikan analisis faktor ekstemal dan faktor internal guna menyiapkan strategi yang seusai dengan keadaan saat ini. Kajian apapun yang digunakan dalam analisis perumusan strategi perusahaan dipastikan melakukan kajian atas hal tersebut. Produk-produk yang perusahaan dibuat melalui suatu proses yang berkualitas akan memiliki sejumlah keistimewaan yang mampu meningkatkan kepuasan konsumen atas penggunaan produk tersebut. Dengan demikian pelanggan mau dan rela untuk kembali menikmati apa yang ditawarkan oleh perusahaan yang menjadi pelanggan setia bagi perusahaan tersebut, karena konveksi merupakan bisnis yang sangat menjanjikan, semua orang pasti membutuhkan pakaian dan sifat dan konveksi tersebut selalu barn dan waktu ke waktu. Hal ini dikarenakan konveksi memiliki beberapa keunggulan yaitu konveksi memiliki target pasar yang mudah dijangkau, tidak membutuhkan banyak biaya angkut, tingginya permintaan produk konveksi seperti pakaian, dan tidak membutuhkan modal besar.

Berikut akan disajikan tabel yang menunjukkan perkembangan jumlah toko konveksi di Kecamatan Terara:

Tabel 1, Perkembangan Usaha Konveksi di Kecamatan Terara Tahun 2014-2017

\begin{tabular}{|c|c|}
\hline TAHUN & JUMLAH TOKO \\
\hline 2014 & 7 \\
\hline 2015 & 9 \\
\hline 2016 & $\mathbf{9}$ \\
\hline 2017 & 11 \\
\hline
\end{tabular}

Sumber: Data Primer

Tabel 1 menunjukkan perkembangan jumlah toko konveksi di kecamatan Terara. Berdasarkan tabel di atas dapat dilihat bahwa setiap tahun terjadi peningkatan jumlah pengusaha konveksi di Kecamatan Terara. Hal ini menyebabkan meningkatnya persaingan diantara pengusaha konveksi di kecamatan Terara Lombok Timur. Hal ini menunjukkan juga bahwa kebutuhan akan pakaian masih tinggi sehingga dengan adanya usaha-usaha konveksi tersebut dapat mempermudah masyarakat dalam mendapatkan barang yang di inginkan. Oleh karenanya banyak pengusaha yang membuka usaha ini karena menganggap usaha ini sangat menjanjikan untuk kedepannya. Berikut akan disajikan tabel yang memperlihatkan pendapatan usaha konveksi pada tahun 2016: 
Tabel 2, Pendapatan Usaha Konveksi di Kecamatan Terara Selama 5 Tahun

\begin{tabular}{|c|c|c|c|c|}
\hline No & Tahun & $\begin{array}{c}\text { Toko Gina Ria } \\
(\mathbf{R p})\end{array}$ & $\begin{array}{c}\text { Toko Susali } \\
(\mathbf{R p})\end{array}$ & $\begin{array}{c}\text { Toko Malika } \\
(\mathbf{R p})\end{array}$ \\
\hline 1. & 2012 & 103.705 .000 & 1.490 .935 .000 & 927.526 .000 \\
\hline 2. & 2013 & 1.159 .050 .000 & 1.612 .935 .000 & 1.049 .526 .000 \\
\hline 3. & 2014 & 1.281 .050 .000 & 1.734 .935 .000 & 1.171 .526 .000 \\
\hline 4. & 2015 & 1.403 .050 .000 & 1.856 .935 .000 & 1.293 .526 .000 \\
\hline 5. & 2016 & 1.525 .050 .000 & 1.978 .935 .000 & 1.415 .526 .000 \\
\hline
\end{tabular}

Sumber: Data Primer

Berdasarkan Tabel 2 dapat dilihat bahwa pendapatan usaha konveksi di Kecamatan Terara mengalami peningkatan setiap tahunnya. Toko Susali memiliki pendapatan tertinggi di antara kedua toko lainnya, karena toko tersebut lebih besar dan lebih maju dibandingkan kedua toko Iainnya. Berdasarkan tabel di atas dapat dilihat pula bahwa posisi pendapatan UD. Gina Ria berada di tengah-tengah, maksudnya adalah pendapatan UD. Gina Ria berada di bawah Toko Susali dan berada di atas Toko Malika. Hal ini mengidentifikasikan bahwa Toko Susali menjadi pemimpin pasar, sementara Gina Ria menjadi penantang pemimpin pasar, dan Toko Malika menjadi pengikut penantang pemimpin pasar. Oleh karena itu dalam penelitian ini, penulis lebih memfokuskan pada Toko UD. Gina Ria sebagai obyek penelitiann.

Dalam proses pendistribusian barang UD. Gina Ria melakukan melalui penjualan ke agen-agen penjualan yang telah menjadi langganan bagi UD. Gina Ria. Dalam hal ini pendistribusian yang dilakukan dapat menjangkau secara luas dan biaya yang minim. Karena distributor dan UI). Gina Ria tersebar di berbagai daerah dan wilayah Lombok hingga wilayah pulau Sumbawa.

UD. Gina Ria melalukan promosi melalui mulut ke mulut (mouth to mouth), hal ini dapat dilihat dan konsumen yang datang ke toko untuk membantu mempromosikan tentang UD. Gina Ria. Selain itu UD. Gina Ria juga melakukan promosi melalui harga dimana konsumen yang berbelanja dengan intensitas barang yang banyak akan mendapatkan potongan harga. UD Gina Ria selain menjual produknya secara eceran juga menjualnya dalam bentuk grosiran. Kendala yang sering dihadapi oleh pemilik toko adalah semua produk yang dijual memiliki strategi yang sama dalam pemasarannya. Di toko tersebut pemilik toko sendiri memperkerjakan 4 orang karyawan dan anaknya sendini sebagai penjaga kasir.

UD. Gina Ria tidak hanya menawarkan hasil produk yang dihasilkan sendiri, melainkan menawarkan beberapa produk yang diambil dan luar produksinya, diantaranya peralatan sekolah, baju sehani-hani, baju kantoran, perlengkapan rumah tangga seperti karpet, bed cover, bantal guling, dan asesoris seperti sabuk, topi, sepatu, kaos kaki, kaca mata, sendal dan sebagainya. UD. Gina Ria berusaha melakukan inovasi dan penerapan strategi yang di anggap sesuai untuk bertahan di pasar. Inovasi yang di lakukan oleh perusahaan ini adalah dengan memproduksi beberapa produknya sendiri seperti pakaian dari segala usia dan menerima pesanan jahitan. Hal ini dilakukan untuk melihat peluang usaha konveksi yang dianggap masih terbuka luas dan untuk meminimalkan biaya produksi sehingga harga yang di tawankan bisa lebih bersaing di pasan. Hal tersebut membuat harga menjadi kekuatan UD. Gina Ria.

Dengan latar belakang di atas, maka dengan demikian penulis mengambil judul penelitian ini sebagai berikut: “Analisis Strategi Pemasaran Produk Konveksi dan Asesoris pada toko UD. Gina Ria di Jalan Raya Rarang Kecamatan Terara Timur Lombok Timur". 


\section{METODE PENELITIAN}

Dalarn pelaksanaanya penelitian ini rnenggunakan jenis penelitian deksriptif. Penelitian deskriptif merupakan penelitian yang berusaha mendeskripsikan dan menginterpretasikan sesuatu misalnya, kondisi atau hubungan yang ada, pendapatan yang berkembang, proses yang sedang berlangsung, akibat atau efek yang terjadi tentang kecendrungan yang tengah berlangsung.

Penelitian ini dilakukan di UD. Gina Ria, yang merupakan salah satu usaha konveksi dan penjualan aksesoris yang cukup berkembang yang berlokasi di Desa Rarang, Kecamatan Terara, Kabupaten Lombok Timur.

Metode pengumpulan data yang digunakan dalarn penelitian ini adalah metode studi kasus yaitu data yang diperoleh dan satu objek penelitian tertentu dalam hal ini UD. Gina Ria. Penelitian ini memfokuskan secara intensif pada satu obyek tertentu yang rnempelajaninya sebagai suatu kasus.

Teknik pengumpulan data yang digunakan didalam peneltian ini adalah sebagai berikut.

a. Observasi

Yakni teknik pengumpulan data yang dilakukan dengan mengamati secara Iangsung obyek penelitian, dengan tujuan untuk menyajikan gambaran realistik perilaku atau kejadian. Observasi merupakan suatu proses yang kompleks, suatu proses yang tersusun dan berbagai proses biologis dan psikhologis. Dua di antara yang terpenting adalah proses-proses pengainatan dan ingatan. Sutrisno Hadi daLam Sugiyono (2013:145).

b. Wawancara

Wawancara merupakan pertemuan dua orang untuk bertukar informasi dan ide melalui tanya jawab, sehingga dapat dikonrtuksikan makna dalam suatu topik tertentu. Esterberg dalarn Sugiyono (2013:231). Wawancara digunakan sebagai teknik pengumpulan data apabila peneliti ingin melakukan studi pendahuluan untuk menemukan permasalahan yang harus diteliti dan untuk mengetahui hal-hal yang lebih dalam dan responden itu sendiri.

c. Dokumentasi

Dokumentasi adalah mencari dan mengumpulkan data mengenai hal-hal yang berupa catatan, transkip, buku, surat kabar, majalah, notulen, rapot, agenda dan sebagainya. (Arikunto, 2014:274).

Variabel yang akan dianalisis dalam penelitian ini adalah variabel internal dan eksternal perusahaan yang yang berpengaruh terhadap strategi perusahaan.

1. Lingkungan Internal:.

> Produk yaitu: sesuatu yang ditawarkan oleh Toko UD. Gina Ria kepada pasar sebagai pemenuhan kebutuhan atau keinginan pasar yang bersangkutan.

$>$ Harga jual kepada konsumen UD. Gina Ria yang dapat dibandingkan dengan pesaing.

$>$ Tempat yaitu pengelolaan saluran perdagangan yang dilakukan oleh Toko UD. Gina Ria untuk menyalurkan produk dan untuk melayani pasar sasaran.

$>$ Promosi yaitu proses yang dilakukan oleh Toko UD. Gina Ria untuk membujuk pasar tentang produk yang ditawarkan inelalui ikian, penjualan pribadi promosi penjualan, maupun publikasi. 
$>$ Bentuk fisik yaitu suatu hal yang secara nyata turut mempengaruhi keputusan konsumen untuk membeli dan rnenggunakan produk jasa yang ditawarkan oleh Toko UD. Gina Ria itu sendiri.

$>$ Orang yaitu semua pelaku yang memainkan peranan penting dalam penyajian jasa pada Toko UD. Gina Ria sehingga dapat mempengaruhi persepsi pembeli.

$>$ Proses yaitu semua prosedur aktual, mekanisme dan aliran aktivitas yang digunakan untuk penyampaian jasa pada Toko UD Gina Ria.

2. Lingkungan Eksternal:

$>$ Konswnen adalah setiap orang yang pemakai barang atau jasa yang disediakan oleh Toko UD. Gina Ria, baik bagi kepentingan din sendiri ataupun orang lain. Konsurnen dapat dibedakan menjadi dua yaitu konsumen antara dan konsumen akhir. Konsurnen antara adalah konsuinen yang menggunakan produk yang ditawarkan.

$>$ Toko UD. Gina Ria sebagai bagian dan proses produksi dan suatu produk lainnya. Sementara konsumen akhir adalah pengguna akhir dan suatu barang yang ditawarkan oleh UD Gina Ria.

$>$ Persaingan adalah proses sosial yang melibatkan Toko UD. Gina Ria untuk berlomba dan berbuat sesuatu demi rnencapai kemenangan tertentu. Persaingan dapat terjadi apabila beberapa pihak menginginkan sesuatu yang terbatas atau sesuatu yang menjadi pusat perhatian umum.

$>$ Kebijakan ekonorni adalah tindakan-tindakan yang dilakukan oleli peinerintah dalam bidang ekonomi yang memberikan dampak pada Toko UD. Gina Ria, Ta menciptkana sistem untuk menentukan nilai-nilai dan pelnungutan pajak, anggaran pernerintah, panawaran uang dan tingkat suku bunga dan hal lainnya yang berkaitan dengan bidang ekonomi yang mampu mempengaruhi harga suatu barang dan jasa di pasar.

Analisis SWOT digunakan untuk mengidentifikasi berbagai faktor secara sistematis untuk merumuskan strategi perusahaan. Analisis SWOT membandingkan antara faktor eksternal perusahaan yaitu peluang (opportunities) dan ancaman (treaths) dengan faktor internal perusahaan yaitu kekuatan (strenghts) dan kelemahan (weaknesses).

\section{HASIL DAN PEMBAHASAN}

\section{Gambaran Umum Objek}

UD.Gina Ria merupakan usaha yang bergerak pada bidang konveksi pakaian dan juga aksesoris lainnya seperti ikat pinggang, topi, tas dan masih banyak lainnya. UD.Gina Ria berlokasi di di Jalan Raya Rarang Kecamatan Terara Timur Lombok Timur.

\section{Analisi Data}

\section{Analisis Posisi Perusahaan Dengan Analisis SWOT}

Analisis posisi perusahaan dengan analisis SWOT yaitu dengan pemberian bobot dan skor terhadap faktor-faktor strategis pada perusahaan baik itu pada faktor strategis internal kekuatan (strength) dan kelemahan (weaknesseses) maupun faktor strategis eksternal peluang (opportunities) dan ancaman (threats).

1. Indikator Kekuatan Perusahaan sebagai berikut:

a. Lokasi UD.Gina Ria yang strategis.

b. Tenaga kerja yang terampil dan pengalaman. 
c. Produk yang ditawarkan berkualitas.

d. Pelayanan yang diberikan ketika hendak memesan atau membeli produk.

e. Harga yang ditawarkan relatif dapat disesuaikan.

f. Dukungan financial (modal) yang sangat memadai.

g. Toko milik sendiri.

h. Mendesain sendiri produknya.

2. Indikator Kelemahan Perusahaan sebagai berikut:

a. Kekurangan pegawai pada saat moment-moment tertentu.

b. Kurang dalam promosi.

c. Toko yang sempit

3. Indikator Peluang Perusahaan sebagai berikut:

a. Pertumbuhan penduduk yang semakin meningkat yang berpotensi dapat menjadi pelanggan atau konsurnen baru.

b. Tumbuhnya daya beli masyarakat.

c. Terjalinya hubungan kerjasama yang baik dengan supplier

d. Meningkatnya kerjasama danjumlah pelanggan bisnis.

4. Indikator Ancaman Perusahaan sebagai berikut:

a. Munculnya pesaing sejenis.

b. Konsumen yang cukup sensitifterhadap harga yang ditawarkan.

c. Kenaikan harga bahan baku.

\section{Space Matrik}

Selanjutnya untuk mempertahaankan analisa yang diperoleb berdasarkan faktor internal perusahaan (kekuatan dan kelemahan) dan faktor eksternal perusahaan (peluang dan ancaman) maka dapat digunakan space matrik, tujuannya adalah untuk melihat posisi perusahaan. Untuk lebih jelasnya dapat dilihat pada table 3 .

Tabel 3. Hasil Matrik Space Analisis

\begin{tabular}{|c|c|c|c|}
\hline Posisi Faktor Strategi Internal & Rating & $\begin{array}{c}\text { Posisi faktor Strategi } \\
\text { Eksternal }\end{array}$ & Rating \\
\hline Kekuatan keuangan(KU) & & $\begin{array}{l}\text { Stabilitas Lingkungan Bisnis } \\
\text { (SL) }\end{array}$ & \\
\hline 1. Lokasi toko yang strategis & 2 & 1. Munculnya pesaing sejenis & -3 \\
\hline $\begin{array}{l}\text { 2. Tenaga kerja yang terampil dan } \\
\text { pengalaman }\end{array}$ & 4 & $\begin{array}{l}\text { 2. Konsumen yang cukup sensitifterhadap } \\
\text { harga yang ditawarkan }\end{array}$ & -3 \\
\hline $\begin{array}{l}\text { 3. Produk yang ditawarkan } \\
\text { berkualitas. }\end{array}$ & 3 & 3. Kenaikan harga bahan baku. & -3 \\
\hline $\begin{array}{l}\text { 4. Pelayanan yang diberikan ketika } \\
\text { hendak memesan atau membeli } \\
\text { produk. }\end{array}$ & 4 & & \\
\hline $\begin{array}{l}\text { 5. Harga yang ditawarkan relatif } \\
\text { dapat disesuaikan }\end{array}$ & 4 & & \\
\hline $\begin{array}{l}\text { 6. Dukungan financial (modal) yang } \\
\text { sangat memadai }\end{array}$ & 4 & & \\
\hline 7. $\quad$ Toko milik sendiri & $\mathrm{I}$ & & \\
\hline 8. $\quad$ Mendesain produk sendiri & 3 & & \\
\hline Jumlah & 25 & Jumlah & -9 \\
\hline Keuntungan kompetitif (KK) & Rating & Kekuatan Industri (IU) & \\
\hline $\begin{array}{l}\text { 1. Kekurangan pegawai pada saat } \\
\text { moment-moment tertentu }\end{array}$ & -3 & $\begin{array}{l}\text { a. Pertumbuhan penduduk yang semakin } \\
\text { meningkat yang berpotensi dapat } \\
\text { menjadi pelanggan atau konsumen baru. }\end{array}$ & 3 \\
\hline $\begin{array}{l}\text { 2. Lokasi toko yang } \\
\text { sempit }\end{array}$ & -3 & b. Tumbuhnya daya beli masyarakat & 4 \\
\hline
\end{tabular}




\begin{tabular}{|c|c|c|c|c|}
\hline Posisi Faktor Strategi Internal & Rating & \multicolumn{2}{c|}{$\begin{array}{c}\text { Posisi faktor Strategi } \\
\text { Eksternal }\end{array}$} & Rating \\
\hline 3. Kurang agresifdalam promosi & -2 & c. $\begin{array}{l}\text { Pertumbuhan pasar yang semakin } \\
\text { berkembang. }\end{array}$ & $\mathbf{4}$ \\
\hline & & d. $\begin{array}{l}\text { Terjalinnya hubungan kerjasama yang } \\
\text { baik dengan suplier dan pelanggan. }\end{array}$ & $\mathbf{4}$ \\
\hline Jumlah & $\mathbf{- 8}$ & Jumlah & $\mathbf{1 5}$ \\
\hline
\end{tabular}

Sumber : Lampiran

Kekuatan Keuangan (KU) $\quad=25 / 8=3,12$

Keuntungan Kompetitif (KK) $\quad=-8 / 3-2,67$

Stabilitas Lingkungan Bisnis (SL) $=-9 / 3=-3$

Kekuatan Industri (KI) 15/4 =3,75

Berdasarkan analisis space matrik, maka dapat terlihatjelas yaitu:

Sumbu Vertikal (Sumbu Y)

$=$ Kekuatan Keuangan $(\mathrm{KU})+$ Stabilitas Lingkungan Bisnis (SL)

$=3,12+(-3)$

$=0,12$

Sumbu Horizontal (Sumbu X)

$=$ Kekuatan Industri $(\mathrm{KI})+$ Keuntungan Kompetitif $(\mathrm{KK})$

$=3,75+(-2,67)$

$=1,08$

\section{Hasil Analisis SWOT}

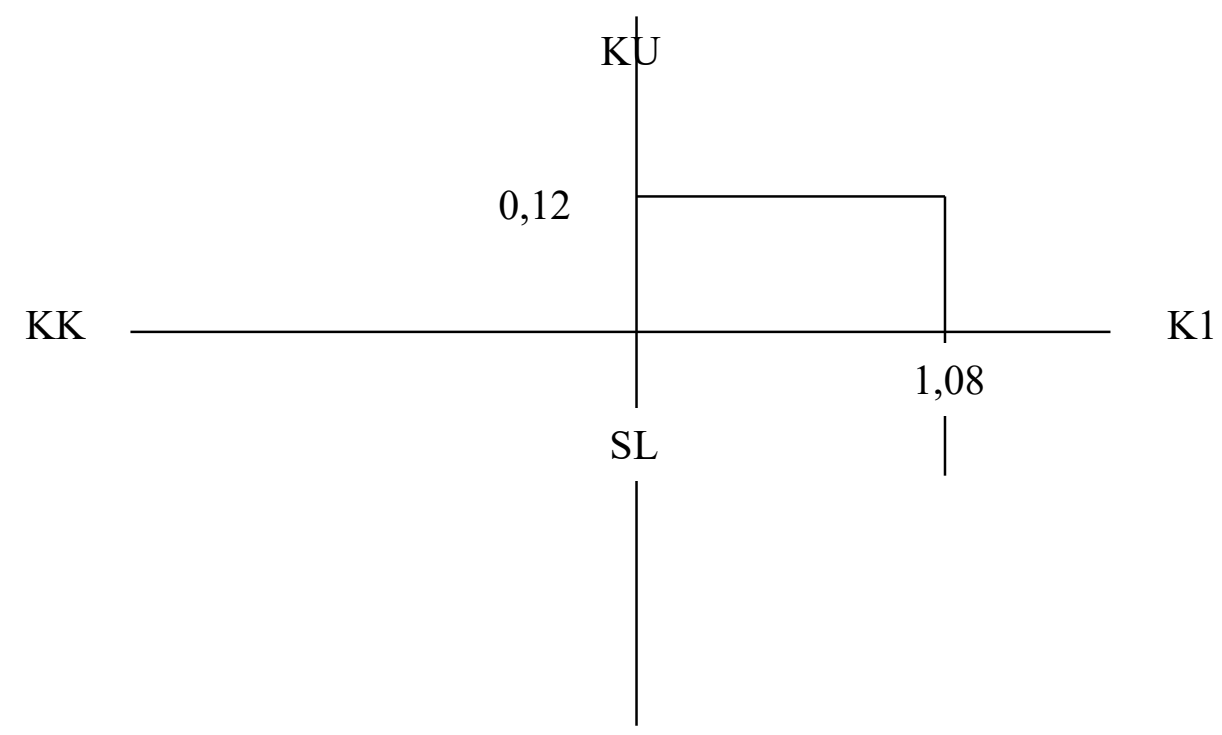

Dan analisis tersebut dapat dilihat bahwa perusahaan berada pada kuadran I, yaitu situasi yang sangat menguntungkan UD.Gina Ria karena memiliki peluang dan kekuatan. Dalam posisi persaingan tesebut maka strategis yang paling tepat untuk diterapkan pada UD. Gina Riaya itu mendukung strategi agresif.

\section{Matrik SWOT}

Untuk menentukan altematif strategi yang sesuai bagi perusahaan adalah dengan membuat Matrik SWOT. Dengan matrik ini dapat digambarkan secara jelas bagaimana peluang dan ancaman eksternal yang dihadapi perusahaan dapat disesuaikan dengan 
kekuatan dan kelemahan yang dimilikinya. Matrik ini dapat menghasilkan empat set kemungkinan altematif yaitu SO, WO, ST. dan WT.

Tabel 4, Hasil Matrik SWOT

\begin{tabular}{|c|c|c|}
\hline EFAS & $\begin{array}{l}\text { Strenght (S) } \\
\text { Lokasi toko yang strategis } \\
\text { Tenaga kerja yang terampil dan } \\
\text { pengalaman } \\
\text { Pelayanan yang diberikan } \\
\text { ketika hendak memesan atau } \\
\text { membeli produk } \\
\text { Harga yang ditawarkan relative } \\
\text { dapat disesuaikan } \\
\text { Dukungan financial (modal) } \\
\text { yang sangat memadai } \\
\text { Produk yang ditawarkan } \\
\text { berkualitas } \\
\text { Toko milik sendiri } \\
\text { Mendesain sendiri produk }\end{array}$ & $\begin{array}{l}\text { Weaknesses }(\mathbf{W}) \\
\text { Kekurangan Pegawai pada } \\
\text { saat moment-moment } \\
\text { tertentu... } \\
\text { Toko yang sempit } \\
\text { Kurang agresif dalam } \\
\text { promosi }\end{array}$ \\
\hline $\begin{array}{l}\text { Opportunities (O) } \\
\text { Pertumbuhan penduduk yang } \\
\text { semakin meningkat yang } \\
\text { berpotensi dapat menjadi } \\
\text { pelanggan atau konsumen baru } \\
\text { Tumbuhnya daya beli } \\
\text { masyarakat } \\
\text { Kerjasama yang baik dengan } \\
\text { suplier dan pelanggan } \\
\text { Meningkatnya kerja sama dan } \\
\text { jumlah pelanggan bisnis }\end{array}$ & $\begin{array}{l}\text { Strategi (SO) } \\
\text { Perluasan pangsa pasar } \\
\text { Meningkatkan jumlah SDM } \\
\text { Memelihara kualitas serta mutu } \\
\text { pelayanan } \\
\text { Meningkatkan promosi }\end{array}$ & $\begin{array}{l}\text { Strategi (WO) } \\
\text { Meningkatkan efisiensi biaya } \\
\text { Mengusahakan } \\
\text { pengembangan dan pelatihan } \\
\text { SDM } \\
\text { Mempertahankan posisi } \\
\text { market leader }\end{array}$ \\
\hline $\begin{array}{l}\text { Treahts (T) } \\
\text { Munculnya pesaing sejenis } \\
\text { Konsumen yang cukup } \\
\text { sensitifterhadap harga yang } \\
\text { ditawarkan } \\
\text { Kenaikan harga bahan baku }\end{array}$ & $\begin{array}{l}\text { Strategi (ST) } \\
\text { Meningkatkan kualitas dan } \\
\text { mum barang maupun pelayanan } \\
\text { Menetapkan strategi harga }\end{array}$ & $\begin{array}{l}\text { Strategi (WT) } \\
\text { Menetapkan strategi bisnis } \\
\text { baru yang lebih efisien dan } \\
\text { efektif } \\
\text { Lebih memperhatikan } \\
\text { kualitas dan mutu pelayanan } \\
\text { terhadap konsumen }\end{array}$ \\
\hline
\end{tabular}

\section{Alternatif Strategi}

Dan hasil analisis faktor kekuatan, kelemahan, peluang dan ancaman yang dimilik UD.Gina Ria yang diformulasikan dengan Matrik SWOT, maka dapat dirumuskan beberapa alternatif strategi yang dapat diterapkan oleh UD.Gina Ria sebagai berikut:

1. Strategi Strenght Opportunities:

a. Perluasan pangsa pasar, yaitu dengan mengadakan kegiatan promosi sehinggan kedepannya perusahaan akan lebih dikenal oleh masyarakat dan bisa meluaskan pasar yang dimiliki. 
b. Meningkatkan jumlah SDM, yaitu dengan menambah jumlah pagawai pada UD.Gina Ria yang bertujuan agar pelayanan yang diberikan kepada konsumen dapat lebih baik lagi.

c. Memelihara kualitas serta mutu pelayanan, yaitu dengan tetap menjaga kualitas dan produk yang ditawarkan oleh UD.Gina Ria

d. Meningkatkan promosi, yaitu dengan lebih gencar melakukan kegiatan promosi agar kedepannya dapat lebih meluaskan pangsa pasar yang ada.

e. Meningkatkan penggunaan modal yang tersedia guna memaksimalkan seluruh sumber daya yang ada.

2. Strategi Strenght Threats:

a. Meningkatkan kualitas dan mutu barang maupun pelayanan, yaitu dengan memperhatikan kualitas dan produk yang dipasarkan agar bisa diterima oleh konsumen dengan baik serta dengan meningkatkan kualitas dan pelayanan yang dibenikan oleh UD.Gina Ria agar konsumen merasa nyaman.

b. Menetapkan strategi harga, yaitu dengan memberikan harga yang lebih murah dibandingkan dengan para pesaing.

3. Strategi Weakness Opportunities:

a. Meningkatkan efisiensi biaya, yaitu dengan membeli barang-barang yang apa saja yang dianggap penting untuk kebutuhan UD.Gina Ria agar barang yang dibeli dapat sesuai dengan kebutuhan dan keinginan konsumen.

b. Mengusahaakan pengembangan dan pelatihan SDM, yaitu dengan memberikan pelatihan kepada pegawai UD.Gina Ria, maksudnya adalah memberikan pelatihan dalam memberikan pelayanan yang baik terhadap konsumen dan memberikan pelatihan agar pegawai tersebut bisa bekerja secara efektifdan efisien.

c. Mempertahankan posisi market leader, yaitu dengan melakukan strategi pemasaran yang tepat untuk tetap mempertahankan posisi yang ada saat ini.

4. Strategi Weakness Threats:

a. Menetapkan strategi bisnis yang baru yang lebih efisien dan efektif, yaitu dengan membuat strategi pemasaran yang barn dan beda dan usaha sejenis lainnya sehingga bisa menanik minat konsumen namun stretegi yang digunakan hams efektif dan efisien.

b. Lebih memperhatikan kualitas mum pelayanan terhadap konsumen, yaitu dengan memperbaiki kualitas dan pegawai yang bekerja di UD.Gina Ria sehingga pelayanan yang diberikan lebih baik terhadap kônsumen yang berbelanja.

\section{Pilihan Strategi}

Altematif pilihan strategi diatas merupakan strategi umum yang masih memerlukan proses pilihan strategi yang mendukung strategi umum yang sesuai dengan kekuatan, kelemahan, peluang dan ancaman yang ada. Berikut beberapa pilihan strategi yang tepat diterapkan oleh UD.Gina Ria, yaitu:

1. Meningkatkan jumlah SDM.

2. Memanfaatkan kekuatan financial yang ada.

3. Meningkatkan promosi.

Penentuan Strategi Level Korporasi dengan Matrik Grand Strategy

Strategi yang dirumuskan pada tingkat korporasi bersifat menyeluruh, mencakup semua kegiatan organisasi termasuk beraneka bidang bersifat bisnis yang ditangani dan semua kegiatan yang bersifat fungsional, bahkan strategi interaksi dengan lingkugan eksternal. 
Berdasarkan hasil analisis SWOT diketahui posisi UD.Gina Ria berada pada kuadran I yaitu kuat/berpeluang. Strategi yang tepat untuk posisi ini adalah mendukung strategi agresif. Strategi ini dilakukan pada perusahaan yang memiliki kondisi posisi persaingan bisnis yang sangat kuat dan daya tank industri yang tinggi. Upaya yang dapat dilakukan adalah dengan lebih meningkatkan perluasan pangsa pasar, meningkatkan kualitas SDM, memelihara kualitas serta mutu pelayanan dan meningkatkan efisiensi promosi.

Dengan penetapan strategi agresif pada level korporasi, maka strategi pada level fungsional khususnya dibidang pemasaran ditunjukkan empat komponen pokok yaitu strategi produk, strategi penetapan harga, strategi promosi dan strategi distribusi.

a. Strategi Produk

Sesuai dengan posisi UD. Gina Ria yang berada pada kuadran I maka strategi yang dipilih yaitu strategi agresif. Hal ini dapat diartikan sebagai upaya untuk mencari dan mengembangkan produk atau pasar yang baru atau bahkan keduanya, dalam rangka mengejar peningkatan volume pejualan pada UD.Gina Ria. Dalam menghadapi tingkat persaingan yang semakin ketat path usaha ini maka UD.Gina Ria menyediakan produk yang berkualitas tinggi dan dapat memenuhi keinginan konsumen sehingga tercipta kepuasan konsumen.

b. Strategi Harga

UD.Gina Ria menetapkan harga jual yang relatif tidak seragam dibandingkan dengan pesaingnya, selain itu UD.Gina Ria juga menerapkan potong harga sesuai dengan kuantitas dan kualitas yang diinginkan oleh konsumen.

c. Strategi distribusi

Altematif strategi distribusi yang dipilih yaitu distribusi langsung. Untuk pemesanan atau booking pemesan produk dapat dilakukan melalui telepon atau datang langsung ke UD.Gina Ria. Namun biasanya path UD.Gina Ria para konsumen yang akan membeli atau memesan produk datang langsung ke toko agar mendapat informasi yang jelas mengenaiproduk yang diinginkan. Ini merupakan salah satu jenis pelayanan yang diberikan oleh UD.Gina Ria dalam upaya mempertahankan dan menciptakan kepuasan bagi konsumen itu sendiri.

d. Strategi Promosi

Promosi yang dilakukan UD.Gina Ria adalah menggunakan media cetak dan internet yang berfungsi sebagai alat untuk memperkenalkan nama dan UD.Gina Ria.

\section{Interprestasi}

Dan data yang diperoleh dan analisis faktor strategi internal dan faktor strategi eksternal tersebut kemudian dipertajam dengan matrik space analysis sehingga diketahui posisi perusahaan dalam analisis SWOT yaitu kekuatan, kelemahan, peluang, dan ancaman yang berada pada kuadran I. liii berarti bahwa posisi UD.Gina Ria kuatJterancam dan didukung dengan strategi agresif.

Hasil analisis data SWOT menunjukkan bahwa UD.Gina Ria masih dalam kondisi yang sangat baik, dan juga memiliki peluang. Dengan kekuatan internal yang dimiliki UD.Gina Ria mampu menanggulangi ancarnan yang berasal dan pesaingnya. Strategi yang tepat untuk UD.Gina Ria adalah strategi agresif. Strategi ini bertujuan untuk mempertahankan posisi perusahaan agar tetap menjadi pemimpin pasar dengan memanfaatkan peluang pasar yang ada.

Strategi pemasaran ini umumnya clilaksanakan oleh perusahaan yang memiliki posisi kompetitif yang kuat. Langkah tepat yang akan dilakukan UD.Gina Ria adalah dengan memaksimalkan kekuatan internal yang dimilikinya untuk merebut pangsa pasar dan diikuti dengan kegiatan promosi yang dilakukan perusahaan, dengan harapan 
perusahaan dapat menanik konsumen sebanyak-banyaknya guna meningkatkan nilai penjualan perusahaan.

\section{Hasil Konfirmasi Strategi Pemasaran Kepada Pemilik UD.Gina Ria}

Setelah melakukan wawancara dengan pemilik UD.Gina Ria dan mendapatkan hasil bahwa posisi UD.Gina Ria adalah berada pada kuadran I yang berarti UD.Gina Ria ini berada dalam posisi kuat dan berpeluang. Pemilik UD.Gina Ria hanya memilih 2 saran dan yang sudah penulis berikan yaitu pemilik UD.Gina Ria memilih meningkatkan jumlah SDM, Memanfaatkan kekuatan financial yang ada. Pemilik toko memilih 2 saran ini karena adanya suatu alasan. Berikut adalah alasan yang diberikan oleh pemilik UD.Gina Ria terkait dengan 2 saran tersebut yang telah diwawancarai:

1. Meningkatkan jumlah SDM dengan tujuan mampu memberikan pelyanan secara optimal dan mampu bekerja secara efektif dan efisien. Hal ini untuk meningkatkan produktifitas dan UD.Gina Ria. Selain itu diharapkan mampu memuaskan konsumen yang datang untuk memsan dan membeli produk yang ada. Dengan meningkatnya jumlah SDM diharapkan agar lebih cepat bisa menyelesaikan pemesanan produk oleh konsumen.

2. Memnfaatkan modal yang ada adalah agar UD.Gina Ria lebih mampu bersaing merebut konsumen. Dengan besarnya modal yang dimilki maka jumlah produk yang tersedia di UD.Gina Ria bisa lebih banyak dan lebih beragam dan sesuai dengan kebutuhan dan keinginan konsumen yang datang ke UD.Gina Ria.

\section{Kesimpulan}

\section{KESIMPULAN DAN SARAN}

Dan berbagai alternatif yang telah dikemukakan pada BAB IV dapat ditanik kesimpulan bahwa berdasarkan hasil analisa data diperoleh hasil UD.Gina Ria berada pada posisi Kuat/Berpeluang dan strategi yang tepat untuk dapat diterapkan pada UD.Gina Ria adalah strategi agresif. Hasil dan analisis SWOT pada UD.Gina Ria adalah:

a. Strenght (kekuatan):

- Lokasi toko yang strategis

- Tenaga kerja yang terampil dan pengalaman

- Pelayanan yang diberikan ketika hendak memesan atau membeli produk.

- Harga yang ditawarkan relatif dapat disesuaikan.

- Dukungan financial (modal) yang sangat memadai

- Toko milik sendiri

- Mendesain sendiri produknya

b. Weakness (kelemahan):

- Kekurangan pegawai pada saat waktu-waktu tertentu..

- Toko yang sempit

- Kurang dalam promosi

c. Opportunities (peluang):

- Pertumbuhan penduduk yang semakin meningkat yang berpotensi dapat menjadi pelanggan atau konsumen baru.

- Tumbuhnya daya beli masyarakat.

- Terjalinnya hubungan kerjasama yang baik dengan suplier

- Meningkatnya kerjasarna danjumlah pelanggan bisnis 


\section{d. Threats (ancaman):}

- Munculnya pesaing sejenis

- Konsumen yang cukup sensitifterhadap harga yang ditawarkan.

\section{Saran}

- Kenaikan harga bahan baku.

Dan beberapa hasil yang dapat disimpulkan pada penelitian i, maka dalam rangka perbaikan perkembangan perusahaan di masa mendatang, ada beberapa saran yang akan disampaikan. Pada proses penentuan strategi sudah tentu harus memperhatikan dan mempertimbangkan faktor internal dan eksternal yang dimilliki perusahaan, masalah satunya dengan mengembangkan strategi agresif. Strategi agresif yang dimaksudkan disini adalah dengan melakukan diversifikasi produk dengan produk yang ditawarkan oleh para pesaing, salah satu caranya adalah UD. Gina Ria tidak hanya sekedar memproduksi produk konveksinya dalam bentuk seragam sekolah, tetapi juga melayani pembuatan sektor produk konveksi lainnya contobnya seragam club bola atau seragam partai atau produk lainnya. Strategi agresif ini dapat dilakiikan dengan cara:

a. Meningkatkan kualitas produk dan jumlah sumber daya manusia

Seperti mengganti alat konveksi yang sudah mulai usang dan dengan menjaga kualitas produk yang ditawarkan dan juga dengan memberikan pelayanan yang ramah dan akrab kepada konsumen, kemudian meningkatkan jumlah sumber daya yang dimiliki oleh UD.Gina Ria tujuannya agar pekerjaan yang dilaksanakan bisa terlaksana dengan baik dan dapat melayani konsumen dengan baik.

b. Meningkatkan promosi

Dengan semakin banyaknya media untuk melakukan promosi maka tidak ada salahnya jika UD. Gina Ria memanfaatkan semua jenis media promosi tersebut misalnya dengan menggunakan media cetak seperti memasang ikian pada koran harian, memasang baliho atau menggunakan selebaran berupa pamfiet. Kemudian melakukan promosi dengan menggunakan media sosial, media ini bisa dimanfaatkan secara baik karena selain banyak orang yang mnggunakan media ini juga terbilang sangat efisisen sehingga jika menggunakan media sosial sebagai media untuk melakukan promosi akan sangat efektif. Kemudian cara yang berikutnya adalah dengan memberikan sponsor pada sebuah acara agar nama dan UD. Gina Ria bisa lebih dikenal oleh masyarakat luas dan secara tidak langsung dapat memperluas pasar yang mereka miliki.

Semua saran yang diberikan tersebut bertujuan untuk dapat memuaskan keinginan konsumen sehingga perusahaan akan mendapatkan keuntungan jangka panjang dan itu semua serta dapat bersaing dengan perusahaan yang menjadi saingannya. 


\section{DAFTAR PUSTAKA}

Adi, Wijaya Arik, 2013. Analisis Strategi Pemasaran Makanan Tradisionl studi kasuspada home industry Rengginang.

Alma, Buchari, 2004.Manajemen pemasaran dan pemasaran jasa. Edisi Revisi, Alfabeta. Bandung.

Anjani, Arin,2015. Analisis Strategi Pemasaran Produk Home Indohome PT. Telkom Kandatel Bantul.

Arikunto, Suharsimi.2014. "Penelitian Tindakan Kelas”. Jakarta:PT Bumi Aksara.

Asihtaiorandgarment. 2015. Manajemen pemasaran konveksi. Diakses path http://asihtailorandgarment.blogspot.co.id/2015/12/manajemen-pemasaran konveksi.html. (tgl 27-12-2016 jam 20.35)

Augusty Ferdinand. 2014, Metode Penelitian Manajemen Pedoman Penelitian untuk Penulisan Skripsi, Tesis, dan Disertasi Ilmu Manajemen, Edisi 3, AGF Books, Fakultas Ekonomika dan Bisnis Universitas Diponegoro, Semarang.

Basu Swastha, DH dan Irawan. 2003. Manajemen Pemasaran Modern, Liberty: Yogykarta.

Chadwick, Bruce A, 1991, Metode Penelitian ilmu Sosial, (terjemahan), Sulistia ML., IKIP Press, Semarang

David, Fred R. 2010. Strategic Management: A Competitive Advantage Approach, Concepts and Cases (13th Edition). Prentice Hall International, London.

Ester Berg, dalam Sugiono, 2013, Metode Penelitian Pendidikan, Alfabeta, Bandung.

Fandy Tjiptono, 2002, Strategi Pemasaran, Andy Offset, Yogyakarta

Ferdinan, Agusty, 2014. Metode Penelitian Manajemen: Pedoman penelitian untuk penuluisan skripsi, tesis dan disertal ilmu manajemen. Semarang: Badan penerbit universitas Diponegoro.

Freddy Ranglcuti. 2009. Strategi Promosi yang Kreatif. Jakarta: Gramedia Pustaka Utama.

Gito Sudarmono, Indrito. 2000. Manajemen Pemasaran. Yogyakarta.

Handoko, T Hani. 2001. Manajemen Personalia dan Sumberdaya Manusia,Edisi Kedua. BPFE, Yogyakarta.

Hurriati.2005. Bauran Pemasaran Dan Loyalitas Konsumen. Cetakan pertama. Bandung:

Alfabeta 
Jatrniko, Rahmad Dwi. (2004). Manajemen Stratejik. Malang: Universitas

Muhammad.Jorfi, Hassan dan Jorfi, saeid dan Yaccob, Hashim fauzy bin. (2011). Relationships among strategic management, strategic behavior, emotional intelligence, IT-business strategic alignment, motivation, and communication effectiveness. International journal of business and management. Vol.6 no.9

Kotler, Philip. 1997. Marketing Management "Analysis, Planning, Implementation and Control” (9 thed.). New Jersey: Prentice Hall International, Inc.

Porter, Michael E, 1993, Strategi Bersaing Teknik Menganalisis Industri dan Pesaing, Edisi Revisi, Erlangga, Jakarta.

Rahmat, maulidia reni, 2012. Analisis Strategi Pemasaran Pada PT. Koko Jaya Prima Makassar. Univesitas Hasanuddin

RangkUti, Fraddy, 2004, Analisis SWOT Teknik Membedah Kasus Bisnis, PT. Gramedia,

Jakarta.

Rangkuti, Freddy, 2001, Analisis SWOT Teknik Membedah Kasus Bisnis, PT. Gramedia, Jakarta

Rangkuti, Freddy. 2009. Strategi promisi yang kreatif dan Analisis Kasus integrated marketing comucation, Jakarta PT. Gramedia pustaka utama.

Reycca.2009. pengertian lingkungan bisnis. Diakses pada http//reycca. Wordpress.comJ/2009/1 1 /08/pengertian-lingkungan-bisnis. (tgl 3-02-2017 jam $11.45)$

Sastradipoera, Komaruddin, 2003, Manajemen Marketing; Suatu Pendekatan Ramuan Marketing, Kappa Sigma, Bandung.

Sugiyono.200 1. Metode Penelitian Bisnis, Bandung, Alfabeta

Sugiyono.2016. Metode Penelitian Kuantitatf Kualitatif Dan R\&D. Bandung

Sutrisno Hadi, dalam Sugiono, 2013, Metode Penelitian Pendidikan, Alfabeta, Bandung.

Suwarsono, Muhammad, 2000. Manajemen Strategik; Konsep dan Kasus, Edisi ketiga, UPP AMP YKPN, Yogyakarta.

Tjiptono, Fandy, 2008, Strategi Pemasaran, Edisi 3, ANDI: Yogyakarta.

Tjiptono, Fandy. 2002 Strategi Pemasaran, Edisi Kedua, AndiOffset, Yogyakarta. 
Tjiptono, Fandy. 2008. Strategi Pemasaran, edisi 111. Yogyakarta: C.V. ANDI Offset.

Venie. 2013. manajemen pemasaran bisni. Diakses path http://venie32.blogspot.co.id/201 3/05/manaiemen-pemasaran-bisnis.html. (tgl 23-12-2016 jam 14.22)

62 | Analisis Strategi Pemasaran Produk Konveksi dan Aksesoris..... 